\title{
A Corpus-Based Study of Malaysian ESL Learners' Use of Modals in Argumentative Compositions
}

\author{
Mohamed Ismail bin Abdul Kader ${ }^{1}$, Neda Begi ${ }^{1}$ \& Reza Vaseghi ${ }^{1}$ \\ ${ }^{1}$ Department of Language and Humanities Education, Faculty of Educational Studies, University Putra Malaysia, \\ Malaysia
}

Correspondence: Mohamed Ismail bin Abdul Kader, Department of Language and Humanities Education, Faculty of Educational Studies, University Putra Malaysia, Malaysia. E-mail: moiskader67@yahoo.co.uk

Received: May 14, $2013 \quad$ Accepted: June 21, $2013 \quad$ Online Published: August 15, 2013
doi:10.5539/elt.v6n9p146

\begin{abstract}
This study attempts to examine the use of English modals in terms of their frequency and functions. For this purpose, Form 4 and College students' argumentative compositions were extracted from the Malaysian Corpus of Students' Argumentative Writing (MCSAW). In order to analyze the data, this study employed discourse analysis and some descriptive statistics by using the WordSmith Tools Version 4.0. The findings of the study showed that Form 4 and College students used can and will more frequently in argumentative compositions compared to other modals. Moreover, the result illustrated the exploitation of present tense form of modal than the past tense form. Finally, it was also revealed that the modals of ability were the most frequent modals found in Form 4 and College students' compositions in terms of their appropriate function. In order to improve the teaching, learning and effective usage of modal auxiliaries among ESL learners, all the central modals must be emphasized repetitively to enhance students' understanding of modals and their functions.
\end{abstract}

Keywords: modal auxiliary verbs, corpus linguistics, discourse analysis, argumentative composition, Malaysian ESL learners

\section{Introduction}

Imparting knowledge on modal auxiliaries to the learners has always been a complicated task for ESL teachers. Likewise, the ESL learners encounter difficulty in learning and using the modal auxiliaries appropriately in their written tasks. DeCarrico (1986) and Hinkel (1995), in their own studies, discovered that L2 learners use modal verbs more in context as opposed to L1 learners. In other words, L2 learners use modals in a different way from L1 learners.

English language learners are required to know the perspective and descriptive rules of the English language in order to be competent and proficient to perform language tasks effectively. Language functions and forms need to be clarified for one to be proficient, and ESL students need different kinds of grammatical knowledge at different stages in their language development (Chitravelu, Sithamparam \& Teh, 1995). The ESL learners need to be familiar with specific grammatical rules in order to perform certain language tasks. Levinson (1983) explains that as the ESL learners progress, it is inevitable for them to be aware of certain grammatical terms like what constitutes a sentence, subject-verb agreement, and others, enough to make them comprehend and able to discuss with the teacher the errors that have been made, and as modal auxiliary is one aspect of grammar, the rules need to be clarified for ESL learners to be able to use it well. Kasper (1979), in his study, demonstrates that German students of English are also doubtful of certain grammatical aspects of English, especially in understanding the pragmatic category of modals and modality in accounting for the differential contextual implications. Undoubtedly, the Malaysian ESL learners could be facing similar problems.

One of the most debated issues for the past thirty years has been the question of the degree to which grammar should be made precise to language learners (Halliday, 1973). In language teaching, it has been strongly disputed whether explicit grammar instruction has a role in second or foreign language classrooms (Ratnawati, 1996). Celce-Murcia and Larsen-Freeman (1983) are adamant that a good knowledge of English grammar is very important for effective teaching to ESL/English as Foreign Language (EFL) learners. Nevertheless, there is an extent of indecision as to what and what not to teach. Teachers have to be positive and know what and how much knowledge to convey to these learners so as to facilitate learners to effectively acquire all four skills in learning 
the second language. This will ensure that these learners eventually become proficient speakers of the target language.

The Malaysian ESL teachers, as stated by Hawanum (2004), being L2 speakers themselves, are often uncertain on how to manage the teaching of grammar to their students. In other words, these teachers are oblivious of how much detail should go into explaining grammatical items. When the Malaysian New English Language Curriculum, based on a communicative model of language teaching learning, was implemented in 1988, the teaching of grammar emerged as problematic (Pillay and North, 1997). Having students of mixed abilities and mixed interests in a classroom has resulted in difficulties for some language teachers (Vethamani, 2001). Therefore, the teachers are imprecise of the role of grammar in the new curriculum and are uncertain of how grammar should be incorporated into the lesson plan.

Due to this uncertainty, ESL/EFL teachers find difficulty to teach one the most integral items among all the grammatical items, the modals. Modals are said to be part of the grammatical items that are considered problematic (Palmer, 1974). It is essential to recognize the problems among Malaysian ESL learners in using modals and find measures to rectify them given that modals play a key role in a sentence or expression. Hence, the present study intends to examine the use of English modals in argumentative compositions of Malaysian ESL Learners at Form 4 and College level in terms of their forms and functions from data made available by the Malaysian Students' Written English Corpus (MSWEC). To this end, the following research questions were formulated:

1) What are the modals used by Malaysian ESL learners in Form 4 and College levels?

2) For what functions are the modals used by the students at Form 4 and College levels?

\section{Literature Review}

\subsection{Modals and Modality}

Modals can define modality and they are part of the grammatical item that is indicated for an ESL learner to understand. According to Quirk and Stein (1990), the learning of grammar in English is a complicated process for a learner of second language because in this process learners have to understand several grammar systems, whereas Greenbaum (1991) saw it as a set of rules that allows the combination of our language words into larger units. On the other hand, Leech, Deuchar and Hoogenraad (1982) believe that grammar is a mechanism in which language works for communicating with other people. They also believe that this mechanism is a set of rules that enables people to put words together in certain ways. So, we should learn grammar rules in order to communicate with other people.

According to Hoye (1997), one of the most important areas in philosophical and linguistic inquiry is the study of modality in the English language. It is stated that the modal auxiliary verbs are used not only to talk about facts but also events or actions which may or may not happen in the future and exist only as conceptions of the mind. So it is obvious that using the modal auxiliary system properly is difficult and Reppen (2002) believes that the similarity in core meaning of few existing modals is the reason behind this difficulty. In addition, Thompson (2002) and other linguists believe that it could be confusing to learn modals because of the meanings that each modal is depicted as. So, in order to be able to teach the ESL learners and avoid confusion and misunderstanding throughout the process of learning modal verbs, it is imperative that teachers of ESL should understand the forms and functions of modal verbs.

\subsection{Modals and Pedagogical Aspects}

The effect of modal auxiliary verbs on the meaning of sentences is one of the main focuses of past researches and it is stated that depending on how it is used, modal auxiliary verbs change the meaning of a sentence (Thompson 2002). According to Leech (1971) and Quirk (1985), modal verbs should be studied by listing and giving each modal the meanings it may have. On the other hand Coates (1983) and Palmer (1990) believe that modality is semantic concepts where each modal may have a list of meanings.

Palmer (1990) believes that epistemic and deontic are two most semantically fundamental kinds of modality and that they are very different from one another. He also states that meanings expressed by modal verbs in English represent modality and reiterates that modality is a semantic term. However, Palmer (1986) later describes modal verbs as a grammatical category, similar to aspect, tense, number, and gender. Su'ad (1999) says that discussions on modal auxiliary verbs in English linguistics have focused on the way in which they affect the meaning of a clause or sentence which they appear in. These are two main approaches to studying modality based on Su'ad:

(1) Listing the modals and giving for each modal the meanings it may have (as in Leech 1971, Quirk et al., 1985), 
(2) Listing modality as semantic concepts and then for each modality giving the list of modals that may express that modality (e.g., Coates, 1983 and Palmer, 1990).

It should be considered that these two versions of studying modality with concern to the terminology involved is an important problem with the scope and treatment it requires in deciding if it is language-based or philosophical. Perkins (1983) says that the orientation of the approach adopted is determining the various answers to "What is modality?" and he believes that in explaining and describing modal auxiliary verbs and modality, semantic concepts of modality and semantically-oriented linguistic units should be considered.

\subsection{Modals in the Malaysian School Curriculum}

In Malaysia there are some confined English words and those words are the only difference between Standard English in Malaysia (the one which is used in formal contexts) and Standard British English. Relatively, Wong (1983) says that interferences from the Malay, Chinese and Indian speech communities have resulted in simplified features of the standard formal L1 speaker of English in the informal ME and this gives rise to variations in phonology, grammar and lexis (Platt and Weber, 1980).

In Malaysia, the following descriptions of modals which are made by Quirk and Greenbaum (1973) are encouraged and now SBrE is the normative for Malaysian usage.

Palmer (1990) says that in standard formal English, the modal auxiliary system is complex and because of that in Malaysian Schools it has been altered and functionally reduced by using fewer and semantically salient modals which serve multi functionality across notions in order to give meaning to the expression of attitudes, assessments and judgements (de Silva, 1981: 12) in colloquial ME to make it more manageable (Wong, 1983).

In the following table some Modals have been listed for comparison purposes. They are stipulated by the KBSR/KBSM Curriculum Specification for English language (MOE, 2003) As it is listed, there are 9 central modal verbs.

Table 1. Modals by the CDC (MOE, 2003) and the Central Modals by Coates (1983), Quirk et al. (1983) and Biber et al. (2003)

\begin{tabular}{lll}
\hline Modals & CDC & Central Modal \\
\hline Can & $\sqrt{ }$ & $\sqrt{ }$ \\
Could & $\sqrt{ }$ & $\sqrt{ }$ \\
May & $\sqrt{ }$ & $\sqrt{ }$ \\
Might & $\sqrt{ }$ & $\sqrt{ }$ \\
Must & $\sqrt{ }$ & $\sqrt{ }$ \\
Should & $\sqrt{ }$ & $\sqrt{ }$ \\
Will & $\sqrt{ }$ & $\sqrt{ }$ \\
Would & $X$ & $X$ \\
Have to & $\sqrt{ }$ & X \\
Need to & $\sqrt{ }$ & \\
\hline
\end{tabular}

Biber et al. (2003) says that the modal have to should be taught alongside the modal must to indicate necessity. The modals which are introduced to students based on the Curriculum Specifications have very limited functions, so students have a tendency to overuse one modal more than the other.

As stipulated by the Curriculum Specifications for English language, the function for each modal is described in the table below: 
Table 2. Modals and Functions According to Curriculum Specifications for English Language (MOE, 2003)

\begin{tabular}{ll}
\hline MODALS & FUNCTIONS \\
\hline May & To show possibility \\
Must & To give advice \\
Have to & To show necessity \\
Could & To show ability \\
Should & To give advice \\
Will & To show future plans \\
Can & To show ability \\
Might & To show possibility \\
Need to & To show necessity, certainty and obligation \\
\hline
\end{tabular}

In comparison to Standard English, the few modals in ME have a greater range of functions and meanings for different modal (Wong, 1983).

The structure of modals are not explicitly taught and only at the Form 4 level were the modals explicitly explained as to what they appear with (Lee, Roberts and Chew, 2002). In other level textbooks, there are no explanations for the modals. The syllabus also gives different meanings to the same modals; for instance the modal must taught in Form 1 shows necessity as opposed to the use of must taught in Form 3 to indicate necessity (MOE, 2003). With all the different meanings of modals, and with no explicit explanation in the textbooks used, this might lead to further confusion for the ESL learners.

Celcie-Murcia and Larsen-Freeman (1983) describe have to as a periphrastic modal, while it is described as a semi-modal or necessity modal by Biber, Conrad and Leech (2002) or semi-auxiliary by Quirk et al. (1985:137). They say that necessity modals or semi-modals are less common than the other modal categories. The modals introduced by the Curriculum Specifications for English language is in the order of: may, must, have to, could, should, will, can, and might (MOE, 2003). Quirk et al. (1985) and Biber, Conrad and Leech (2003) arranged the modal verbs in pairs such as can/could, may/might, shall/should, will/would and must. Ney (1980) agrees with Quirk et al. (1983) and Biber et al. (2003) that modals should be introduced in pairs (the present and the past tense form) as mentioned earlier. However, with the non-standard ME slowly being accepted, students tend to make errors in the use of modals, for example, the modal can in colloquial ME take on many functions as shown below:

(1) You can have this book today (permission)

(2) You can drive? (ability)

(3) Can lend me your bike or not? (willingness)

(4) Can also/ Sure can. (agreement)

(Wong, 1983, p. 137)

All these expressions are acceptable in informal ME although they appear as errors. Certain words and phrases originated during colonial times and have been accepted as ME. This has allowed for more influences coming from the various speech communities and lifestyles.

However, the rules have resulted in typical mistakes made by Malaysian ESL learners, for example in the use of would and could. The examples below are typical sentences made by Malaysian ESL students according to Hughes and Heah (1993, p. 155):

(1) If you turn left at Batu Sembilan you would reach Kampung Chempaka.

(2) Some people would leave their front gates open when they go out. This is foolish because it encourages burglars.

The sentences should be written as:

(1) If you turn left at Batu Sembilan you will reach Kampung Chempaka.

(2) Some people leave their front gates open when they go out ...

Hughes and Heah (1993) discuss in great detail about mistakes made by Malaysian ESL learners in the use of modals. They believe that describing the exact rules for the correct usage of modals is not easy. These mistakes 
made by Malaysian ESL learners led to Hawanum's (2004) conclusion that the teaching of grammar is the most challenging task any Malaysian teacher faces in his or her classroom. Teachers do not know that students need an understanding of the rules to gain fluency as well as accuracy.

Neff et al. (2003) in a study of argumentative texts written in English by student writers (L1 and L2 speakers) found that when comparing how these writers construct stance using modal verbs (can, could, may, might, and must), the L2 speakers overuse or under use modal verbs more than native language speakers. Lots of non-corpus-based studies of modal verbs have shown that L2 speakers of English have many problems in using modal verbs appropriately. They overvalue or under-represent certain modal meanings or form (Hinkel, 1995 and DeCarrico, 1986). Malaysian ESL learners also have the same problem.

The system of modality in Malaysian English has been reduced where fewer modals are used across a wide semantic field (de Silva, 1981). The fewer modals used serve multi-functionally across the notional categories. The modals used are: must for certainty and compulsion; can for permission and ability; and should to a lesser degree for certainty and obligation (de Silva, 1981). Then, there is will for probability and insistence; ought for certainty and obligation; may for possibility and permission; got to be for necessity and obligation; and need for necessity. When described properly ESL learners will be able to use modals appropriately.

\section{Methodology}

This research was designed to investigate Malaysian ESL learners' use of modals in terms of forms and functions in the written argumentative compositions of Malaysian ESL learners, using data from the Malaysian Corpus of Students' Argumentative Writing (MCSAW). The computer-based language corpus was developed over the years and has inspired various studies and results. It includes texts containing hundred thousands of words in context and it makes it possible for researchers to perform frequency counts to disclose interesting patterns in language. The data in this corpus consists of written data, precisely argumentative compositions, from three different levels of students respectively Form Four, Form Five, and College students in the Malaysian education system. The data in the corpus involve only the argumentative essays composed by the students. The students were assigned two essays entitled "Do you think Facebook has more advantages than disadvantages? Discuss your reasons" and "what are the advantages and disadvantages of living in a hostel". They were then asked to write a 250 -word argumentative essay on one of the topics during the class time. The assignment of the topics was stimulated not only by its familiarity to the learners but also by its capability of inspiring them to write productively.

\subsection{Population and Sampling}

For the purpose of this study, the population for the English language corpus was sourced from argumentative compositions written by Form Four, Form Five, and College students in the Malaysian education system. In other words, the population for this study is amassed from Malaysian ESL learners. The corpus used in this study was compiled by Mukundan, J., and Rezvani Khalajahi (2013). The corpus for this study consists of 406, 500 running words (tokens) which have been chosen in order to identify the use of English modals in terms of and functions and the frequency of those modals. The compositions have been written by 1010 students, 404 males and 606 females, respectively, from schools and colleges in Selangor, Negeri Sembilan, Melaka and Kelantan.

\subsection{Instrumentation}

The WordSmith Tools Version 4.0 was employed for the purpose of this research, because it has been recognized as a capable and suitable tool to support quantitative and qualitative data analysis by many researchers (Baker, 2006; Bondi, 2001; de Klerk, 2004; Flowerdew, 2003; Henry \& Roseberry, 2001; Menon, 2009; Mukundan, 2004; Mukundan \& Roslim, 2009; Nelson, 2001; Scott, 2001). It was designed by Mike Scott (1996, 1997, and 1999). WordSmith tools imparts immediate displays of word frequency lists; concordances, which demonstrates all the uses of a given word in its contexts; and lists of keywords (Ghadessy, Henry and Roseberry, 2001). For the purpose of this study only the WordList and Concord tools are used. With the help of the WordList tool of the computer software, the researcher is able to identify the frequency occurrence of the modal auxiliary verbs.

\subsection{Discourse Analysis}

Discourse analysis (DA), or discourse studies, is a broad expression for a number of methods to analyse written, vocal, or sign language use or any significant semiotic event. The objects of discourse analysis are discourse, writing, conversation, communicative event and these objects are differently described in terms of coherent sequences of sentences, propositions, speech acts, or turns-at-talk. In opposition to much of traditional linguistics, discourse analysts not only examine language use 'beyond the sentence boundary', but also favour to analyze 'naturally occurring' language use, not created examples.

For this study, the method of discourse analysis was used to analyze sentences in the written tasks and also to 
identify the function of the modals used. The use of modals in students written work that are examined in this study must be analyzed given that it is a way of communication where modals are used to submit to a stance and the writer's attitude. It is important to know that discourse analysis is used to analyze the data so that language characteristics that extend across clause boundaries can be focused (Biber, Conrad \& Reppen,1998). It is also important to recognize the modals and the functions displayed in the students' writing.

\section{Results and Discussion}

\subsection{Distribution of Modals in Form 4 and College}

The data that was produced by a concordance search of modals used in the students' written work at the Form 4 and College levels supplied the observed figures to distinguish the distribution of modals at the two different levels. In particular, the language software Wordsmith Tools Version 4 was used to sort out the data to arrive at the descriptive statistics. The results are put into a table and discussed according to the two levels in the following sections.

\subsubsection{Form 4 Level}

A number of 296 argumentative compositions were amassed from Form 4 students for this study. And, the modals that appeared at this level were can, could, may, might, must, should, will, would, and need to. The modal 'have to' was not found in any composition. Since some of the modals had been taught in the previous levels, their occurrences at the higher levels would serve to strengthen students' knowledge on their use. A total of 10 different modals were included in the curriculum specifications for English language Form 1-5 but only 9 were found in the argumentative compositions at the Form 4 level. The frequency count of the modals used in the argumentative compositions amounts to 4072 instances as shown in the following table:

Table 3. The Frequency Count of Modals for Form 4 Level

\begin{tabular}{ll}
\hline Modals & Frequency \\
\hline Can & 2439 \\
Could & 104 \\
May & 156 \\
Might & 79 \\
Must & 138 \\
Should & 153 \\
Will & 787 \\
Would & 106 \\
Have to & None \\
Need to & 108 \\
Total & 4072 \\
\hline
\end{tabular}

The figures in Table 3 show that the modal can has the highest frequency of 2439, while the modal might showed the lowest frequency of 79. The modal 'have to' did not appear at all though it is included in the Curriculum Specifications. This modal has the same function as the modal must. The absence of the modal auxiliary verb have to could probably be because the students did not find the situations necessary to use have to in their argumentative compositions. Below are examples of sentences with the modal can found at this level:

1. People can also receive updates in the world of sports, news and other fields such as entertainment.

2. With all these people giving their views, an individual can gain all sorts of information.

Students at this level are more inclined to use can frequently though there are instances in which the use of could would have been more appropriate. The use of could is noticeably low compared to the use of can in the search. Another function is the degree of probability that varies in sentences that use could instead of can, such as in "They could go (if they wanted to)" versus "They can go." In the former sentence, probability is more established than in the latter. Students at the Form 4 level may have not acquired the knowledge of these additional functions of could and thus restrict its use to the "ability" function as a past tense form of can. The sentences below are the examples of only 104 occurrences of could in Form 4 students' argumentative compositions: 
1. We could relax after one whole day of hard work.

2. When we are waiting for someone, we could always play these games to relieve boredom.

The distributions of will and would are identical to modals can and could, where the instances of the present tense form was found to be more than the past tense form. The examples below are some sentences discovered with the use of will:

1. The usage of Facebook could also cause addiction and this will lead to the waste of time.

2. When they returned home, especially hostel students, they will just spend their times with Facebook and not with their family.

The findings demonstrate that will is used much more than would, with 787 instances as contrasting to would with only 106. The examples below show the use of the modal would found in the argumentative compositions of Form 4 students:

1. Furthermore, these communication modes would also help us to keep in touch with our friends.

2. These features would help the members of group to stay connected.

Therefore, there is an obvious disparity, in terms of frequency, between the 10 modals taught. This study exposes that the two most frequently used modals at Form 4 level are can and will. The use of these two most common modals comprised more than half of all modal auxiliary verbs used by the students. However, it is impulsive to make conclusions about students' competence or ability in using the modals particularly those which appear infrequently.

\subsubsection{College Level}

For the purpose of this study, 440 argumentative compositions were collected and analyzed. The distribution of modal auxiliary verbs in these compositions demonstrates the use of can, could, may, might, must, should, will, would, and need to. The modal 'have to', similar to Form 4 students' compositions, was not found. The distribution of the modals used in the argumentative compositions at this level amounts to 5731 instances as shown in the following table:

Table 4. The Frequency Count of Modals for Collage Level

\begin{tabular}{ll}
\hline Modals & Frequency \\
\hline Can & 3698 \\
Could & 122 \\
May & 123 \\
Might & 86 \\
Must & 143 \\
Should & 246 \\
Will & 1052 \\
Would & 101 \\
Have to & None \\
Need to & 160 \\
\hline Total & 5731 \\
\hline
\end{tabular}

The figures shown in Table 4 exhibit that modals can and will are more frequently used compared to other modal verbs. The use of can dominates $64.5 \%$ of the overall distribution of modal verbs in the compositions while will shows $18.3 \%$ of use. The modal verb might displays the lowest frequency among all the modals used by the College level students as it shows only $1.5 \%$. Below are the examples of sentences that show the use of can and will:

Can:

1) Facebook is also a source of information and news where the users can stay updated with latest news and updates. 
2) Through Facebook, we can get new friends from all over the world.

Will:

3) Major news usually goes viral on Facebook and surely the users will not be lagged behind.

4) They will not complete their homework.

The high frequency of can and will compared to other modal verbs is possibly a result of the argumentative nature of the student essays. And again, the absence of have to could probably be for the reason that the students did not come across the situations in which have to is appropriate in their argumentative compositions.

\subsubsection{Summary of Research Question 1}

The results of the concordance search of modals spotted in the argumentative compositions at the two educational levels reveal interesting patterns. The results show that students use can and will more frequently in argumentative compositions at both the Form 4 and College levels. The figures also illustrate that students at these levels exploit more present tense form of the modal than the past tense form. This is clear as the distribution of can is the highest at both levels. Moreover, the results of the study found no instances of 'shall' in the two levels. This finding is consistent with the ones found by Biber (2003). He asserted that "considering the pairs of central modals, the tentative/past time member is less frequent than its partner in all cases except shall/should". At the higher level, these students would have already learnt most of the modals, alongside other language units, and therefore were competent to make use of a range of modals in their argumentative compositions appropriately. This indicates that students' knowledge of modals has enhanced at this point of time and the students have obtained most of the modals with their functions. The students were also able to select modals according to the suitable situations. A similar pattern of use was identified with the modal will.

The modals can and will, the most favoured modals in Form 4 and College students' argumentative compositions are actually the English equivalents of "boleh" and "akan" which are commonly used in Malay. This would be a causal factor to the high frequencies of can and will in these argumentative compositions. Reasonably, Oxford (1990) stated that the use of the mother tongue is one of the strategies used by ESL learners to overcome limitations in the target language, and since more than $69.8 \%$ of the students from the Malaysian Students' Written English Corpus (MSWEC) were Malays, and Bahasa Melayu (Malay Language) is the first language, this could be the reason for the high occurrence of the modal can. The other modals might have occurred infrequently for the reason that they are more formal than can and will. The findings also confirmed that can was used more at the two levels in comparison to the modal could. The similar pattern was found for the modals will/would and may/might.

\subsection{Modals and Their Functions as Used by the Students at the Two Levels}

Students, both at Form 4 and College level, used each modal to perform different functions in their argumentative compositions. Therefore, the distribution of the function that each modal refers to is listed to explain the differences. All the sentences which included modals were identified in the argumentative compositions and listed according to the levels. Subsequently, the modals were analysed according to their functions. The functions stipulated in the Curriculum Specifications for the English language was used to serve this purpose. The functions of the modals are categorized and discussed as shown in the following table:

Table 5. Aggregated Counts of Modal Use and Function in the Students' Compositions

\begin{tabular}{lllll}
\hline \multirow{2}{*}{ Modals } & Form 4 & \multicolumn{3}{c}{ College } \\
\cline { 2 - 5 } & $\begin{array}{l}\text { Correct } \\
\text { use }\end{array}$ & $\begin{array}{l}\text { Total } \\
\text { occurrences }\end{array}$ & $\begin{array}{l}\text { Correct } \\
\text { use }\end{array}$ & $\begin{array}{l}\text { Total } \\
\text { occurrences }\end{array}$ \\
\hline $\begin{array}{l}\text { Modals of Ability } \\
\text { (can, could) }\end{array}$ & 2472 & 2543 & 3799 & 3820 \\
$\begin{array}{l}\text { Modals of Probability } \\
\text { (will, would, may, might })\end{array}$ & 992 & 1128 & 1349 & 1362 \\
$\begin{array}{l}\text { Modals of Necessity/Certainty/Obligation } \\
\text { (should, must, have to, need to })\end{array}$ & 356 & 399 & 532 & 549 \\
\hline
\end{tabular}




\subsubsection{Modals of Ability}

The modals of ability are can and could. Table 5 shows the distribution of the correct use of modals of ability in the argumentative compositions at the two levels. The correct use of modals of ability shows a progression from Form 4 to College level. At Form 4 level, can and could has the frequency of 2472 correct function occurrences from a total of 2543 frequencies. However, the frequency of correct use of function for modals of ability increases at the College level to $99.4 \%$ compared to $97.2 \%$ at the Form 4 level. The correct use of modals of ability, can and could, are depicted in the following examples:

Can:

1) Besides that, we can meet them face to face by using video call.(Form 4)

2) In this way, we can share knowledge and experiences, interest and opinion from a wider group of people. (College)

Could:

3) The usage of Facebook could also cause addiction and this will lead to the waste of time. (Form 4)

4) In fact, it could help us to share anything that could be useful to others. (College)

\subsubsection{Modals of Probability}

Table 5 also illustrates the appropriate use of modals for probability and their distribution in the two argumentative compositions. Modals of probability include will, would, may, and might. They also necessarily indicate a future event. The probability of the future event ranges from certainty to probability. Therefore, will indicates the certainty of an event happening and the other modals a probability. The figures in table 5 demonstrate an increase in the number of correct use of modals of probability from Form 4 to College level. The correct use of modals of probability at Form 4 level scores $87.9 \%$ compared to $99.0 \%$ at College level. The correct use of modals of probability is shown in the following examples:

Will:

1) Facebook will lead school students to play games, chatting, reading their friends status, poking and doing kind of things other than their homework during their bored time. (Form 4)

2) With just typing the name of the friend in facebook, we will find him. (College)

Would:

3) They would be sitting in front of the computer most of the time eating snacks and without doing any physical activities. (Form 4)

4) Agencies would not be convinced with their abilities if they cannot speak verbally well. (College)

May:

5) This may lead to unfinished assignments. (Form 4)

6) This situation may lead us to other serious problems later on. (College)

Might:

7) If we play with Facebook too much we might get bad eye sight immediately. (Form 4)

8) They might fall asleep when the teacher is teaching. (College)

\subsubsection{Modals of Necessity/Certainty/Obligation}

The modals categorised as modals of necessity and obligation include should, must, have to and need to. Table 5 shows the frequency of the correct use of the modals of necessity/obligation. Surprisingly, out of the four modals of necessity/obligation, should seem to be used the most with 399 instances across the two levels; 153 occurrences at the Form 4 level and 246 instances at the College level. This points out that to indicate necessity, students prefer to use should over all the other modals of the same category. The occurrence of have to at both levels is rare and there was not even one instance of have to found at both levels. In general, students do not seem to prefer to use the modal have to, even if they do have the knowledge of it. In general, the use of correct modals of necessity/certainty/obligation appears to be more dominant at College level with $96.9 \%$ compared to $87.2 \%$ at Form 4 level.

\subsubsection{Summary for Research Question 2}

The modals identified in the argumentative compositions were the modals stipulated in the KBSR/KBSM syllabus. 
Their frequencies of correct occurrence of modals according to the function and the increase from Form 4 to College level suggest students' acquired knowledge of modals and their functions. Malaysian ESL learners have a great propensity to over-use and under-use specific modals and functions. This was observed to be true as the students did make use of the same modals often and others on the odd occasions. The modals stipulated in the syllabus are divided into three categories: modals of ability, modals of probability and modals of necessity/obligation. Table 5 proves that the modals of ability are the most frequent modals found in the students' compositions with a total of 6271 correct occurrences in terms of their function from Form 4 to College level. This indicates that the modals of ability are preferred and used more frequently than the other modals. This is due to the fact that modals can and could are easier to acquire and use by the students in their writing to indicate ability more than other functions of modality. Also, the most common Malay modal is 'boleh' by observation and by research (Imran Ho, 1993), which is the corresponding modal of can in English.

However, the low frequencies of the modals of probability/possibility and modals of necessity/certainty do not signify that students have not gained the knowledge but the findings point to the fact that students may have been in the process of acquiring the modals as they move along but were only competent enough to produce the modals at the higher level. The students at the two levels were able to use the modals stipulated by the syllabus rather appropriately.

\section{Conclusion and Implications}

This study investigated Malaysian ESL learners' use of modals in their written task. The concepts under this study were related to how correctly and appropriately modal verbs are used in their writing. Most of the key conclusions that has become clear throughout the findings are basically associated to usage of modal auxiliary verbs by Malaysian ESL learners. The most apparent conclusion is that the most common modals used by the students were the modals of ability that include can and could. It was also found that students did not find difficulty in deciding on the appropriate modals with the respective appropriate functions. Among the modals of necessity/certainty/obligation, should was more frequently used by both levels of students. Finally, students at Form 4 and College levels were also able to use modals that are stipulated in the syllabus appropriately.

Though the findings show that the students at both levels have used the modals appropriately, all the central modals must be emphasized repetitively to enhance students' understanding of modals and their functions. This is because there is a noticeable inequality between the use of can and will and the other modal verbs. Furthermore, reinforcement on the forms and functions of modal auxiliary verbs has to be continued so that the students will be able to use different but correct modals evenly. The modals of probability and the modals of necessity/certainty/obligation, for instance, were identified to be used infrequently at both levels designating students' lack of expertise in using these two modal verbs. Teachers must emphasize these two modal auxiliary verbs in order to develop better comprehension and understanding among students to use these two modals appropriately and more frequently.

The findings of the study revealed that there are some difficulties that Malaysian ESL learners encounter in recognizing and using modals. One of these difficulties is related to modals' meaning and function which led to the misuse of modals. Another major difficulty that was found based on results of the study is lack of an equivalent modal verbs system in Malaysian. This issue hinders Malaysian ESL learners to learn modals. Therefore, teachers and curriculum stakeholders should raise students' awareness to the importance and negative results of misusing modals.

\section{References}

Baker, P. (2006). Using Corpora in Discourse Analysis. London: Continuum.

Biber, D., Conrad, S., \& Leech, G. (2002). Longman students grammar of spoken and written English. Essex: Pearson Education.

Biber, D., Conrad, S., \& Leech, G. (2003). Longman students grammar of spoken and written English. Essex: Pearson Education.

Biber, D., Conrad, S., \& Reppen, R. (1998a). Corpus linguistic: investigating language structure and use. Cambridge: Cambridge University Press.

Biber, D., Conrad, S., \& Reppen, R. (1998b). Corpus Linguistics. Cambridge: Cambridge University Press.

Bondi, M. (2001). Small corpora and language variation: Reflexivity across genres. In M. Ghadessy, A. Henry, \& R. Roseberry (Eds.), Small corpus studies and ELT (pp. 135-174). Amsterdam/ Philadelphia: John Benjamons Co. 
Celcie-Murcia, M., \& Larsen-Freeman, D. (1983). The Grammar book: an ESL/EFL teacher's course. USA: Newbury House. 654.

Chitravelu, N., Sithamparam, S., \& Teh Soo Choon. (1995). ELT Methodology : Principles and Practice. Shah Alam: Penerbit Fajar Bakti.

Coates, J. (1983). The semantics of the modal auxiliaries. London: Croom Helm. 269.

De Klerk, V. (2004). The use of 'actually' in spoken Xhosa English: A corpus study. World Englishes, 24(3), 275-288. http://dx.doi.org/10.1111/j.0883-2919.2005.00410.x

De, Carrico, J. (1986). Tense, aspect, and time in the English modality system. TESOL Quaterly, 20, 665-682.

De, Silva, E. (1981). Forms and functions in Malaysian English: the case of modals. SARE, 3, 11-23.

Flowerdew, L. (2003). A combined corpus and systematic-functional analysis of the problem solution pattern in a student and professional corpus of technical writing. TESOL Quarterly, 37(3), 489-511. http://dx.doi.org/10.2307/3588401

Ghadessy, M., Henry, A., \& Roseberry, R. (Eds.) (2001). Small corpus studies and ELT. Amsterdam/ Philadelphia: John Benjamons Co.

Greenbaum, Sidney. (1991). 'ICE: the International Corpus of English', English Today, 28, 3-7.

Halliday, M. A. K. (1973). Explorations in the Functions of Language. London: Arnold.

Hawanum, Hussein. (2004). Using simple poems to teach grammar. The Internet TESL Journal, 10(5).

Henry, A., \& Roseberry, R. L. (2001). Using a small corpus to obtain data for teaching a genre. In M. Ghadessy, A. Henry, \& R. Roseberry (Eds.), Small corpus studies and ELT (pp. 93-113). Amsterdam/ Philadelphia: John Benjamons Co.

Hinkel, E. (1995). The use of modal verbs as a reflection of cultural values. TESOL Quaterly, 29(2). 325-342.

Hoye, L. (1997). Adverbs and modality in English. London: Longman.

Hughes, R., \& Heah, C. (1993). Common errors in English: grammar exercises for Malaysians. (2nd Ed.). Shah Alam: Fajar Bakti.

Imran, Ho, Abdullah. (1993). The semantics of the modal auxiliaries of Malay. Kuala Lumpur: Dewan Bahasa Pustaka.

Kasper, G. (1979). Communication strategies: modality reduction. Interlanguage Studies Bulletin Utrecht, 4(2), 266-283.

Lee, A., Roberts, L., \& Chew, M. (2002). English Form, 4. Johor Bahru: PGI Cipta Sdn. Bhd.

Leech, G., Deuchar, M., \& Hoogenraad, R. (1982). English grammar for today: a new introduction. London: Macmillan Education.

Leech, Geoffrey, N. (1971). Meaning and the English Verb. London: Longman.

Levinson, Stephen, C. (1983). Pragmatics. Cambridge, England: Cambridge University.

Malaysia, Ministry of Education. (2003). Curriculum specifications for English language form 4. Kuala Lumpur: Curriculum Development Centre.

Menon, U. (2009). Language in India. Strength for Today and Bright Hope for Tomorrow, 9(12), December 2009. ISSN 1930-2940.

Mukundan, J. (2004). A Composite Framework for ESL Textbook Evaluation. PhD Thesis. Universiti Putra Malaysi.

Mukundan, J., \& Rezvani Kalajahi, S. A. (2013). Malaysian Corpus of Students' Argumentative Writing (MCSAW). Australia, Australian International Academic Center.

Mukundan, J., \& Roslim, N. (2009). Textbook Representation of Prepositions. English Language Teaching, 2(4), 123-130.

Neff, J., Dafouz, E., Herrera, H., Martinez, F., Rica, J., \& Diez, M., et al. (2003). Contrasting Learner corpora: the use of modal and reporting verbs in the expression of writer stance. In S. Granger, \& S. Petch-Tyson (Eds.), Extending the scope of corpus-based research: New applications, new challenges. Amsterdam - New York: Rodopi. 
Nelson, M. (2001). A corpus based study of business English and business teaching. Oxford: Oxford University Press.

Ney, J. W. (1980). Teaching the English modals. RELC Journal, 11(1), 35-42.

Oxford, R. (1990). Language learning strategies: what every teacher should know. New York: Newbury House.

Palmer, F. R. (1990). Modality and the English modals. London: Longman.

Palmer, F. R. (1974). The English verb. London: Longman.

Perkins, Michael, R. (1983). Modal Expressions in English. Norwood, New Jersey: ABLEX Publishing Co.

Pillay, H., \& North, S. (1997). Tied to the topic: integrating grammar and skills in KBSM. The English Teacher, 26.

Platt, John, \& Heidi, Weber. (1980). English in Singapore and Malaysia: Status, features, functions. Kuala Lumpur: Oxford University Press.

Quirk, R., \& Stein, G. (1990). English in use. London: Longman.

Quirk, R. (1985). A Comprehensive Grammar of English Language. London: Longman.

Quirk, R., \& Greenbaum, S. (1973) A University Grammar of English. London, Longman.

Quirk, R., Greenbaum, S., Leech, G., \& Svartvik, J. (1985). A comprehensive grammar of the English language. London: Harlow.

Ratnawati, M. A. (1996). The English language syllabus for the year 2000 and beyond - lessons from the views of teachers. The English Teacher, 25, 4-10.

Reppen, R. (2002). Using corpora to explore linguistic variation. Amsterdam: John Benjamins.

Scott, M. (2001). Comparing corpora and identifying key words, collocations and frequency distributions through WordSmith Tolls suite of computer programs. In M. Ghadessy, A. Henry, \& R. L. Roseberry (Eds.), Small Corpus Studies and ELT (pp. 47-67). Amsterdam / Philadelphia: John Benjamins Publishing Co.

Scott, M. (1996), Wordsmith Tools. Oxford: Oxford University Press.

Scott, M. (1997), Wordsmith Tools version 2. Oxford: Oxford University Press.

Scott, M. (1999), Wordsmith Tools version 3. Oxford: Oxford University Press.

Su'ad, Awab. (1999). Multi-word units in a corpus-based study of memoranda of understanding: modal multi-word units. Lancaster: Lancaster University. PhD Thesis [unpublished].

Thompson, M. (2002). Modals in English language teaching. Retrieved April 26, 2004, from http://www.telusplanet.net/linguisticsissues/modalsinteaching.html

Vethamani, M. E. (2001). 'What English do we teach?' The English Teacher.

Wong, I. (1983). 'Simplification features in the structure of colloquial Malaysian English'. In Noss, R. (Ed.), Varieties of English in South East Asia (pp. 125-149), Singapore: Singapore University Press (for SEAMEO).

\section{Copyrights}

Copyright for this article is retained by the author(s), with first publication rights granted to the journal.

This is an open-access article distributed under the terms and conditions of the Creative Commons Attribution license (http://creativecommons.org/licenses/by/3.0/). 